UNDERGRADUATE RESEARCH IN NATURAL AND CLINICAL SCIENCE AND TECHNOLOGY (URNCST) JOURNAL Read more URNCST Journal articles and submit your own today at: https://www.urncst.com

\title{
The University of Ottawa Healthcare Symposium (UOHS) 2021 Pitch-O-Rama: Elevator Pitch Research Competition
}

Nicole Chu, BSc Student [1]*, Tanya Li, BSc Student [1]*, Michelle Hong, BSc Student [1], Hanbyoul Agatha Park, BSc student [2]

[1] Faculty of Science, University of Ottawa, Ottawa, Ontario, Canada. K1N 6N5

[2] Faculty of Medicine, University of Ottawa, Ottawa, Ontario, Canada. K1N 6N5

*Corresponding Authors: nchu024@uottawa.ca, tli135@uottawa.ca

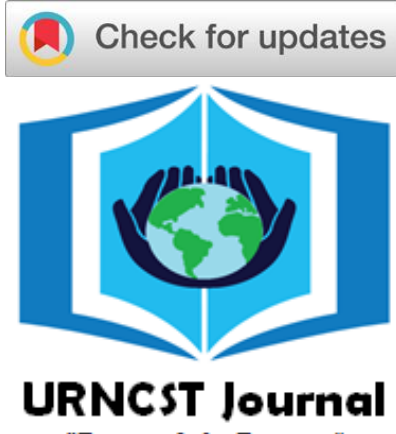

"Research in Earnest"

\begin{abstract}
The University of Ottawa Healthcare Symposium (UOHS) is a one-day undergraduate health conference that aims to increase awareness of the interdisciplinary field of health. This conference engages students' interest in health through seminars, interactive panel discussions, and a research-based elevator pitch competition. UOHS was created eleven years ago by undergraduate students and has grown to become the University of Ottawa's largest healthcare conference. Every year, UOHS hosts an event called the Pitch-O-Rama, during one of the conference's seminar blocks. This event is an elevator pitch competition where individuals have the opportunity to present their health care-related research to an audience and panel of judges in a clear and engaging way. The goal of the Pitch-O-Rama is to have students communicate and share their scientific research to the community. The written submissions of the top 3 winners are highlighted in this abstract book.
\end{abstract}

Keywords: Pitch-O-Rama; elevator pitch competition; healthcare; stem cell therapy; myocardial infarction; cryopreservation; betaine; determinants of health; pediatric care

Table of Contents

Top Three UOHS 2021 Pitch-O-Rama Abstracts

pg. A1-A2

\section{Conference Abstracts}

Note: These abstracts have been reproduced directly from the material supplied by the authors, without editorial alteration by the staff of the URNCST Journal. Insufficiencies of preparation, grammar, spelling, style, syntax, and usage are the authors.

\section{Top 3 UOHS 2021 Pitch-O-Rama Abstracts}

Stem cell therapy for heart failure: Medical breakthrough, or dead end?

Mathieu Rheault-Henry [1], Ian White [1], Rony Atoui, MSc, MD [2,3]

[1] Faculty of Medicine, Northern Ontario School of Medicine, Sudbury, Ontario, Canada, P3E 2C6

[2] Department of Cardiac Surgery, Health Sciences North, Sudbury, Ontario, Canada, P3E $3 Y 9$

[3] Associate Professor of Surgery, Northern Ontario School of Medicine, Sudbury, Ontario, Canada, P3E 2C6

Heart failure continues to be one of the leading causes of morbidity and mortality worldwide. The primary causative agent of chronic heart failure is myocardial infarction which results in cardiomyocyte necrosis and the subsequent formation of fibrotic scar tissue. Currently, pharmacological and non-pharmacological therapies focus on managing symptoms of heart failure rather than reversing underlying cardiac pathologies. Heart transplantation usually cannot be relied on, as there is a major discrepancy between the availability of donors and recipients. As the heart lacks significant endogenous regenerative potential, heart failure carries a poor prognosis and high mortality rate. Novel therapeutic approaches have incorporated the use of stem cells as a vehicle to treat heart failure, as they possess the ability to self-renew and differentiate into multiple cell lineages and create various tissue types. Past, present, and future clinical trials, factors that influence stem cell therapy outcomes as well as ethical and safety considerations will be discussed. Preclinical and clinical studies have shown a wide spectrum of outcomes when applying stem cells to improve cardiac function. This may reflect the infancy of clinical trials and the limited knowledge on the optimal cell type, dosing, route of administration, patient parameters and other important 
UNDERGRADUATE RESEARCH IN NATURAL AND CLINICAL SCIENCE AND TECHNOLOGY (URNCST) JOURNAL Read more URNCST Journal articles and submit your own today at: https://www.urncst.com

variables that contribute to successful stem cell therapy. Nonetheless, the field of stem cell therapeutics continues to advance at an unprecedented pace. We remain cautiously optimistic that stem cells will play a role in heart failure management in years to come.

Inhibition of ice recrystallization and cryoprotective activity of betaine Stephanie Bogdan, BSc Student [1], Robert Ben, PhD [2]

[1] Faculty of Medicine, University of Ottawa, Ottawa, Ontario, K1N 6N5

[2] Faculty of Science, University of Ottawa, Ottawa, Ontario, K1N 6N5

Preserving biological specimens such as individual cells or biological tissues has proven to be crucial in regard to cell-based therapeutics. Unfortunately, current cryopreservation protocols remain suboptimal, reducing the potency of cellular products being developed for cell and gene therapy applications in modern medicine. To minimize cellular damage from ice recrystallization during freezing and thawing, cryopreservation techniques require the use of ice recrystallization inhibitors or cryoprotectants to help maintain cellular viability and metabolic functions post-thaw. Currently, a commonly used but relatively toxic cryoprotectant is dimethyl sulfoxide. Betaine is an organic molecule that has recently been claimed to function as a cryoprotectant. Here, we hypothesize that betaine has the ability to inhibit ice recrystallization and thus reduce cryoinjury as well as enhance post-thaw cell viability and functionality. The cryopreservation properties of commercially available betaine hydrochloride salt will be quantitatively assessed using an ice recrystallization inhibition assay and the compound's cytotoxicity potential will be assessed using a Resazurin assay on HepG2 cell cultures. Given acceptable result profiles form these two techniques, a modified AnnexinV/Sytox ISHAGE cytometry gating strategy in appropriate adherent and non-adherent cells will be performed to measure post-thaw cell viability. If results demonstrate betaine to effectively inhibit ice recrystallization while increasing post-thaw recoveries and functionality, then this would indicate its potential for use as an ice recrystallization inhibitor instead of the relatively toxic cryoprotectant, dimethyl sulfoxide. Thus, insight obtained from this project could play a key role in implementing the use of cellular therapies in a clinical environment.

\section{Shades of care: Understanding how BIPOC* mothers and children experience paediatric care in Ontario, Canada Raisa Ladha, MSc Candidate [1] \\ [1] Faculty of Applied Health Sciences, University of Waterloo, Waterloo, Ontario, N2L $3 G 1$}

*Black, Indigenous and People of Colour

Race and ethnicity are determinants of health which play significant roles in shaping the quality of care and health outcomes for a child. BIPOC families disproportionately experience barriers in accessing and receiving paediatric care across Canada. The effects of these barriers are further pronounced when it is the child's mother who serves as their proxy, ultimately setting BIPOC children on a trajectory for negative health outcomes in the future. The purpose of this study is to further understandings of how BIPOC mothers and children experience paediatric care in Ontario. It will additionally conceptualize the provider-patient relationship from the perspective of BIPOC mothers, as well as clarify their needs and expectations in order to positively engage with and receive paediatric health care services. The participant sample consists of BIPOC mothers residing in Ontario for at least 6 months, who have required paediatric care for their children (birth to age 5). 20 semistructured interviews are being conducted and the stories that participants share will be examined through narrative analysis. Contributions of this research are 3-pronged: (1) identifying the healthcare needs of paediatric patients and their families; (2) enhancing cross-cultural understanding; (3) informing clinical practice. This study will also provide direction as to what sorts of approaches must be taken in order to sustainably implement culturally safe and collaborative paediatric care across Ontario.

\section{Conflicts of Interest}

The authors have no conflicts of interest to declare.

\section{Authors' Contributions}

NC: Co-Vice-President of Communications, serving as the planning committee for the University of Ottawa Healthcare Symposium 2021 Pitch-O-Rama, assisted authors with their abstract submissions, drafted the conference abstract booklet, and gave final approval of the version to be published. 
UNDERGRADUATE RESEARCH IN NATURAL AND CLINICAL SCIENCE AND TECHNOLOGY (URNCST) JOURNAL Read more URNCST Journal articles and submit your own today at: https://www.urncst.com

TL: Co-Vice-President of Communications, serving as the planning committee for the University of Ottawa Healthcare Symposium 2021 Pitch-O-Rama, assisted authors with their abstract submissions, drafted the conference abstract booklet, and gave final approval of the version to be published.

MH: Co-Chair of the planning committee for the University of Ottawa Healthcare Symposium 2021, gave final approval of the version to be published.

HAP: Co-Chair of the planning committee for the University of Ottawa Healthcare Symposium 2021, gave final approval of the version to be published.

\section{Acknowledgements}

We want to acknowledge the entire University of Ottawa Healthcare Symposium 2020 Executive Team and volunteers for playing an integral role in helping to make this year's first virtual conference: "Unite and Ignite" a success. The competition would also not have been possible without our judges, Dr. Shawn Aaron, Dr. Kathy-Sarah Focsaneanu, Samantha Buchanan and Krystina Clarke. Your valuable time and feedback to the participants are very much appreciated and will undoubtedly have a positive impact on their future success.

\section{Funding}

The University of Ottawa Healthcare Symposium elevator pitch research competition is sponsored by the Faculty of Science, the Office of the Vice-Provost, Research, and the Office of the Vice-Provost, Academic of the University of Ottawa.

\section{Article Information}

Managing Editor: Jeremy Y. Ng

Article Dates: Received Feb 28 21; Published Mar 1921

\section{Citation}

Please cite this article as follows:

Chu N, Li T, Hong M, Park HA. The University of Ottawa Healthcare Symposium (UOHS) 2021 Pitch-O-Rama: Elevator pitch research competition. URNCST Journal. 2021 Mar 19: 5(3). https://urncst.com/index.php/urncst/article/view/252 DOI Link: https://doi.org/10.26685/urncst.252

\section{Copyright}

(C) Nicole Chu, Tanya Li, Michelle Hong, Hanbyoul Agatha Park. (2021). Published first in the Undergraduate Research in Natural and Clinical Science and Technology (URNCST) Journal. This is an open access article distributed under the terms of the Creative Commons Attribution License (https://creativecommons.org/licenses/by/4.0/), which permits unrestricted use, distribution, and reproduction in any medium, provided the original work, first published in the Undergraduate Research in Natural and Clinical Science and Technology (URNCST) Journal, is properly cited. The complete bibliographic information, a link to the original publication on http://www.urncst.com, as well as this copyright and license information must be included.
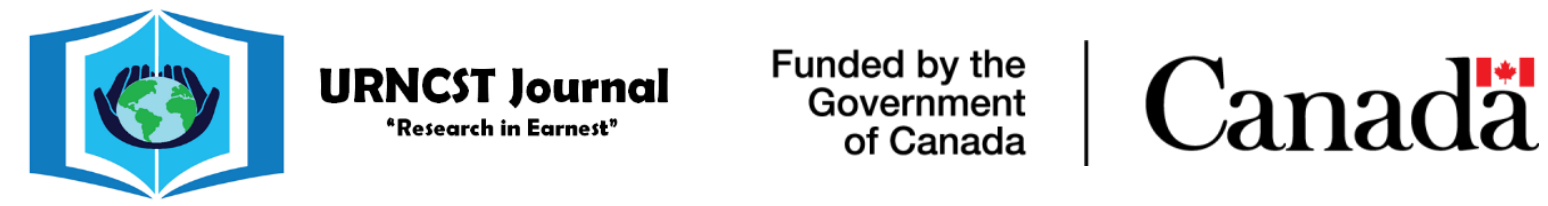
Do you research in earnest? Submit your next undergraduate research article to the URNCST Journal! | Open Access | Peer-Reviewed | Rapid Turnaround Time | International | | Broad and Multidisciplinary | Indexed | Innovative | Social Media Promoted |

Pre-submission inquiries? Send us an email at info@urncst.com | Facebook, Twitter and LinkedIn: @ URNCST Submit YOUR manuscript today at https://www.urncst.com! 